\title{
On the identity and occurrence of Rubus racemosus (Rosaceae) in India with note on its neotypification
}

\author{
Bhavadas $\mathrm{N}^{1^{*}}, \mathrm{~K}$ M Prabhukumar ${ }^{2} \&$ Umesh B $\mathrm{T}^{3}$ \\ ${ }^{1}$ Research and Development Centre, Bharathiar University, Coimbatore 641 046, Tamil Nadu, India \\ ${ }^{2}$ Centre for Medicinal Plants Research, Arya Vaidya Sala, Kottakkal, Malappuram 676 503, Kerala, India \\ ${ }^{3}$ Department of Bioscience, MES college, Marampally, Aluva, Kerala 683 107, India
}

\section{Article history}

Received: 30 March 2019

Accepted: 12 July 2019

Published: 28 July 2019

\section{Publisher}

Horizon e-Publishing Group

\author{
*Correspondence \\ Bhavadas N \\ \bhavadas1988@gmail.com
}

\begin{abstract}
Rubus racemosus is an endemic species of Rosaceae and the distribution is strictly restricted to southern parts of the Western Ghats. The present paper provides a detailed taxonomic description, colour photographs and discusses the taxonomic affinity of the taxon with its allied taxa. And also, the name Rubus racemosus is neotypified here.
\end{abstract}

Keywords: endemic; neotype; Rubus; Rosaceae; southern Western Ghats

Citation: Bhavadas N, Prabhukumar KM, Umesh BT. On the identity and occurrence of Rubus racemosus (Rosaceae) in India with note on its neotypification. Plant Science Today 2019; 6(3):342-345. https://doi.org/10.14719/pst.2019.6.3.541

\begin{abstract}
Copyright: (c) Bhavadas et al (2019). This is an open-access article distributed under the terms of the Creative Commons Attribution License, which permits unrestricted use, distribution, and reproduction in any medium, provided the original author and source are credited (https://creativecommons.org/licenses/by/4.0/).
\end{abstract}

Indexing: Plant Science Today is covered by Scopus,Web of Science, BIOSIS Previews, ESCI, CAS, AGRIS, CABI, Google Scholar, etc. Full list at http://www.plantsciencetoday.online

\section{Introduction}

Rubus Linnaeus (1) is one of the largest genera in the family Rosaceae comprises about 1546 species (2) distributed mainly in temperate to subtropical regions of the northern hemisphere (3), especially in south-eastern Asia, east Asia and northern part of south America (4). In India, over 75 species of Rubus has been reported so far (5), out of which nine were reported to occur in southern parts of the country (6, 7). As a part of the ongoing taxonomic revision of the genus Rubus in southern Western Ghats, the authors came across an interesting specimen of Rubus, growing in patches of evergreen forests at Kothagiri in the Nilgiri Biosphere Reserve, Tamil Nadu. On careful scrutiny of protologue, other pertinent literature (6-8), protologue and voucher specimens in different herbaria, its identity has been confirmed as Rubus racemosus Roxb. (9), an endemic species of the region.

During the study, we came across the specimens of $R$. racemosus are misidentified in various Indian herbaria with its allied taxa $R$. niveus Thunb. Even though both the species shows some morphological similarities (pinnately compound leaf with 3-5 leaflets, white tomentose on abaxial surface, pink coloured flowers etc.) we can differentiate $R$. racemosus from the later by means of the absence of white glaucous on stem, presence of red glandular hairs on stem, branchlets, petiole, petiolule, peduncle, pedicel and sepals, and large flowers upto $1.2 \mathrm{~cm}$ long. The existence of overlapping characters (leaf character, flower colour, etc.) between the species and the lack of detailed description of the taxon might have led to this misidentification. 

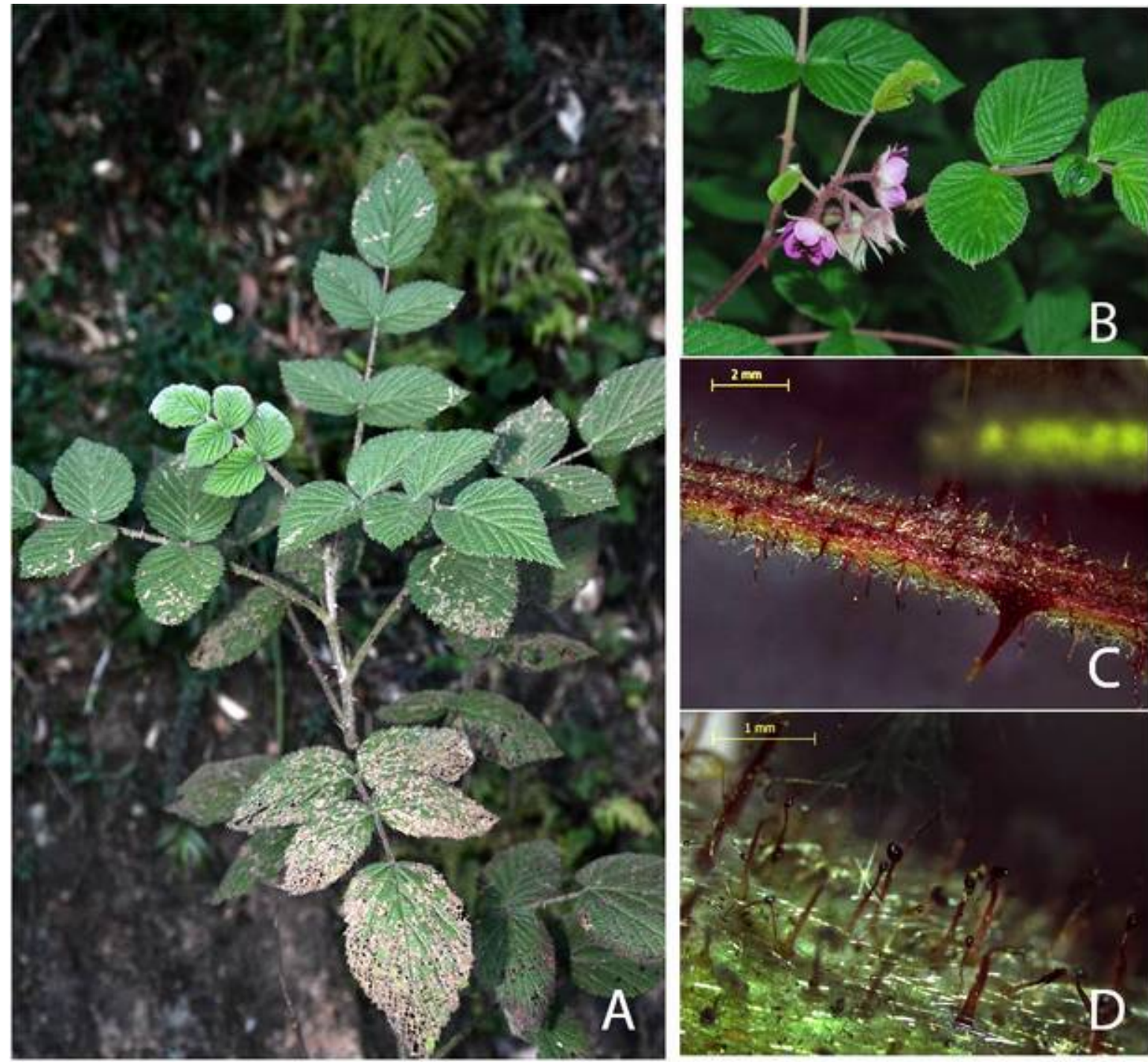

Fig. 1. Rubus racemosus Roxb. (A) habitat; (B) inflorescence; (C) glandular hispid on stem; (D) glandular hair

Hence, a detailed taxonomic study was done and elaborated description has been prepared based on live collections. While looking on its nomenclature, the need of neotypification of the name $R$. racemosus has been identified and thus a neotype has been designated here for the name as per Art. 9.8 of Schenzhen Code (10).

\section{Taxonomical treatment}

Rubus racemosus Roxb., Hort. Bengal. 92. 1814 \& Fl. India 2: 519. 1832; Hook. f. Fl. Brit. India 2: 340. 1878; Gamble, Fl. Madras 442. 1919; Manilal, Fl. Silent Valley 99. 1988; Sivar. \& P. Mathew, Fl. Nilambur 248. 1997; K.M. Matthew, Fl. Palni Hills 445. 1999; Fyson, Fl. S. Indian Hill Stat. 1: 195. 1932; Fyson, Fl. S. Indian Hill Stat. 2: 148. 1932; Fyson, Fl. Nilgiri \& Pulney Hill Top. 2: 97. 1915; Fyson, Fl. Nilgiri \& Pulney Hill Top. 1: 134. 1920.

Neotype (designated here):- India, Tamil Nadu, Thriunelvelli District, Naterical, $\pm 1100 \mathrm{~m}$, 24.9.1967, E. Vajravelu, 29293 (MH00233480 image)!.
Erect or straggling, armed shrub, reaching 1-4 $\mathrm{m}$ high. Stem terete, green, densely covered with red-glandular hairs throughout, not thick tomentum; prickles stout, distantly arranged, 1-6 mm long, thick, straight or curved, reddish. Stipules prominent, 1-1.4 cm long, linear or linearlanceolate, margin entire, apex acute, pubescent on both surfaces. Leaves imparipinnate, petiolate; petioles terete, 1-8 cm long, glandular- pubescent, reddish; prickles thick, c. $3 \mathrm{~mm}$ long, reddish. Leaflets 3-5 (7), sub chartaceous, petiolulate; petiolules of lateral leaflets subsessile, terete with reddish glandular hairs and a few prickles; petiolule of terminal leaflets $1.3-3.5 \mathrm{~cm}$ long, terete, glandular, reddish hairy with a few prickles. Blades of the lateral leaflets $2-4.5 \times 1-2.3 \mathrm{~cm}$ long, lanceolate or ovate-lancolate; the terminal leaflets often larger than the lateral ones, often sublobulate, 4-6.5 × 1.5-4 cm long, elliptic, ellipticovate or lanceolate; base rounded, margins serrated or double serrated, serrations 7-8 mm deep, apex acute, pubescent on both surfaces, white-tomentose beneath, younger leaflets more velvety than mature ones; prickles present on lower surface of veins, reddish, c. $1 \mathrm{~mm}$ long; leaflets penniveined with 5-8 pairs of lateral veins, brochidodromous; midrib and 


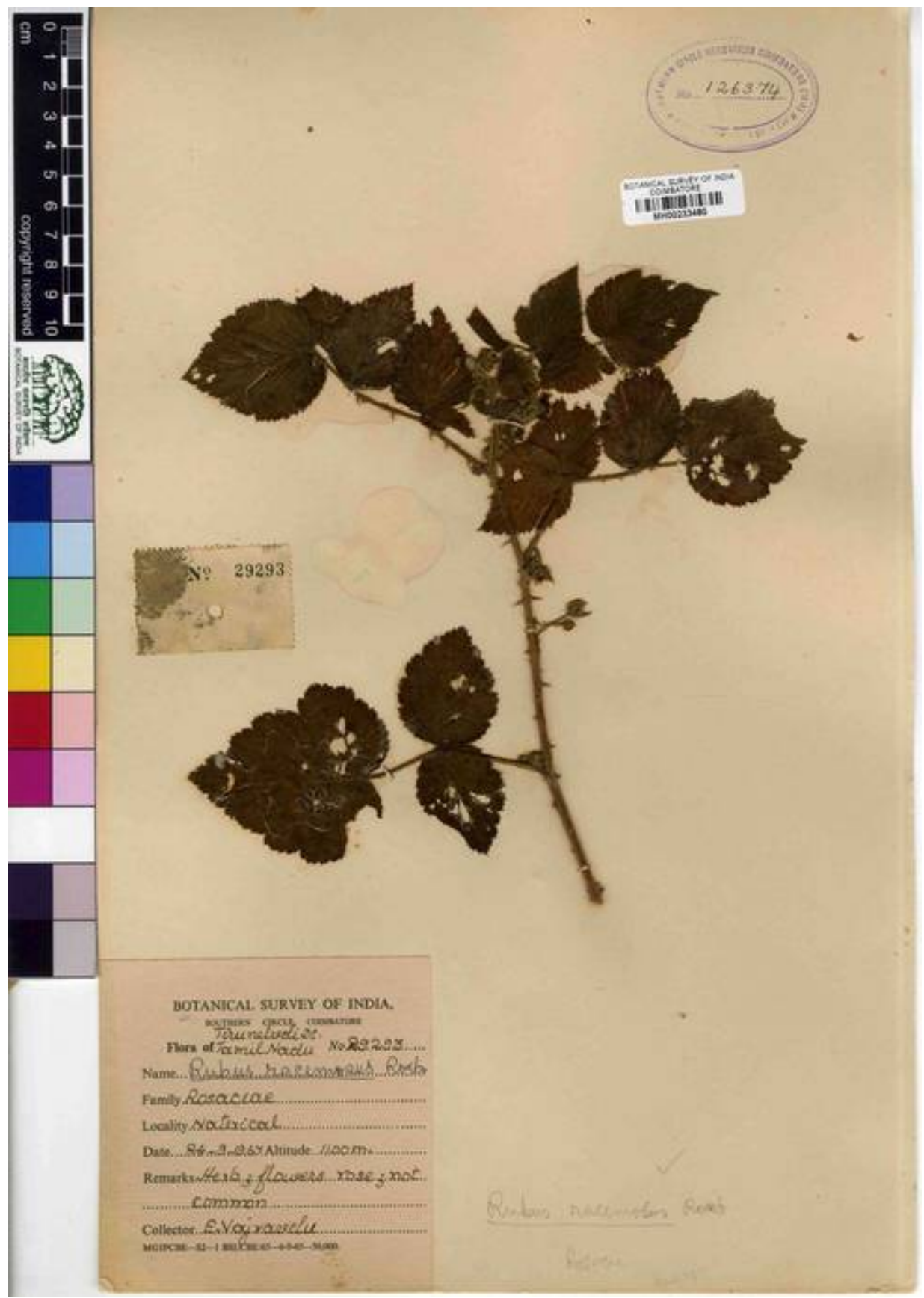

Fig. 2. Digital image of chosen neotype of Rubus racemosus Roxb. housed at MH

lateral veins more raised beneath. Inflorescence raceme, axillary or terminal, 3-5 flowered; peduncles 2-3 cm long, terete, densely covered with glandular hairs. Flowers pink or red, bisexual and actinomorphic. Bracts $5-6 \mathrm{~mm}$ long; lanceolate or subulate. Pedicels 1-1.5 cm long, terete, reddish glandular hairs. Calyx 5 lobed; lobes free, 1-1.2 $\times$ $0.5-0.8 \mathrm{~cm}$ long, lanceolate or ovate, margin entire, apex acuminate, glandular pubescent on both surfaces. Petals 5, free, 1-1.2 cm long, as long as the calyx lobes, obovate-truncate, pink or red. Stamens numerous; filaments up to $3.5 \mathrm{~mm}$ long, glabrous, creamy with pink at apex; anther 2 celled, c. $1 \mathrm{~mm}$ long, brown. Carpels numerous; ovary c. $5 \mathrm{~mm}$ long, oblique ovoid, green; style $3-4 \mathrm{~mm}$, pink; stigma entire. Drupelets aggregate, globose, c. $1 \mathrm{~cm}$, white tomentose, purple inside (Fig. 1).

Phenology: December-April.
Habitat and Ecology: Rubus racemosus is usually seen in higher elevation between 1100 and $2300 \mathrm{~m}$. It grows in open areas, shola-grassland ecotone, road sides of forest areas and disturbed forest patches.

Distribution: Rubus racemosus is endemic to southern Western Ghats (7).

Taxonomic affinity: $R$. racemosus most closely resembles with $R$. niveus Thunb. from south India. Sometimes, at juvenile stage it may look alike $R$. ellipticus, due to the presence of reddish hair on the stem. Previous reports revealed that the colour of petals in $R$. racemosus is mentioned as red. However, during the present study it has been observed that the petals are initially pink but after anthesis, it turns to red. The same kind of changes in petal colour also noticed in $R$. odoratus. 
In the flora of the Nilgiri and Palney Hill tops, Fyson (11) mentioned two forms of $R$. racemosus, hairy forms and glabrous forms. But during the revisionary studies, we are failed to locate the glabrous form and our specimens exactly matches with Fyson's hairy forms.

Etymology: The specific epithet, 'racemosus' refers to the majestic appearance of raceme inflorescence, which looks majestic in this species.

Cytology: 2n= 14 (12)

Nomenclature Notes: William Roxburgh (9) proposed the name $R$. racemosus (9) based on his collection from mountains of Mysore and also provided a note on this species in an unpublished manuscript (13). In the protologue, the provenance was quoted as "a native of the mountains of Mysore”. In the Flora of British India, Hooker (8) mentioned that, he had failed to trace out authentic specimen's of Roxburgh's plant for reference. Our efforts also to trace out the specimens from BM, BR, CAL, CALI, K, P and RHT herbaria are in vain, and our personal communication with personnel in concerned herbaria confirmed that, no original material referred to $R$. racemosus is extant. Hence, the name warrants the need of neotypification. During the herbarium consultation at $\mathrm{MH}$, we have succeeded to locate some specimens of $R$. racemosus from Tamil Nadu collected by recent researchers. Of which, the specimen collected by Vajravelu in 1967 from Tamil Nadu (MH00233480) is well preserved with flowers and the characters are perfectly fit with the protologue, hence the same is selected here as the neotype of the name according to the ICN Art. 9.8 of Shenzhen Code (10) (Fig. 2).

Specimen examined: India, Kerala, Silent Valley National Park, $\pm 2200 \mathrm{~m}, 25.3 .1982$, T. Sabu 10324 (CALI!); India, Kerala, Sispara, 27.2.1983, Philip Mathew 34010 (CALI!); Tamil Nadu, Nilgiris district, Nanjanad, 26.3.1950, G.H. Maduram 93962 (MH!); Carriott Shola, 5.2.1971, J.L. Ellis 37869 (MH!); India,; Naduvattam, Pykkara, 22.11.2007, M. Mohanan \& J.V. Sudhakar 120376 (MH!); Mukkurthy National Park, $\pm 2275 \mathrm{~m}, 23.11 .2007$, M. Mohanan \& J.V. Sudhakar, 120407 (MH!); Mukurthy National Park, $\pm 2200 \mathrm{~m}, 29.1 .2008$, K. Althaf Ahmed Kabeer 121610 (MH!); Western Catchment 1, 14.4.2008, M. Mohanan \& J.V. Sudhakar 122276 (MH!).

\section{Acknowledgements}

The authors are grateful to the authorities of BM, $\mathrm{BR}, \mathrm{CAL}, \mathrm{CALI}, \mathrm{K}, \mathrm{P}$ and RHT herbaria for giving permission to consult the herbarium and also providing digital images of specimens. Authors are also thankful to Dr. Indira Balchandran, Director, Centre for Medicinal Plant Research (CMPR), Malappuram for the facilities given and Mr. V.V.
Naveen Kumar, for providing support and encouragements.

\section{Competing interest}

Authors have no competing interest to declare.

\section{Author's contributions}

BN collected the specimen as part of Ph D work, analysed, filed data and wrote initial manuscript. KMP supervised the work and provided technical and academic support. UBT mentored the Ph D work.

\section{References}

1. Linnaeus C. Species Plantarum, Vol. 1. Laurentii Salvii, Stochholm (Holmiae); 1753. pp. 560.

2. Plants of the World Online. Royal Botanic Gardens Kew. Available from: www.plantsoftheworldonline.org (accessed 07 May 2019).

3. Lu LD, Boufford DE. Rubus L. In: Wu ZH, Raven PH (eds.) Flora of China, 9. Science Press, Beijing and Missouri Botanical Garden Press, St. Louis; 2003. pp. 195-286.

4. Kalkman C. Rosaceae. In: Flora Malesiana, Flowering Plants Seri.I-Spermatophyta, Vol. 11: 1993. pp. 227-351.

5. Gupta C, Dash SS, Brach AB. Lectotypification of two names in the genus Rubus L. (Rosaceae). Phytotaxa 2016; 266: 297-300. https://doi.org/10.11646/phytotaxa.266.4.8

6. Gamble JS. Rubus Linn. In: Flora of the Presidency of Madras Vol 2. Adlard \& Son, Ltd., London; 1919. pp. 439442.

7. Sasidharan N. Biodiversity Documentation for Kerala. Part.6: Flowering Plants. Kerala Forest Research Institute, Peechi; 2004. pp. 166-167.

8. Hooker JD. Rosaceae. In: Hooker, JD (Ed.) The Flora of British India. Vol 2. L. Reeve \& Co., London; 1878. pp. 307-342.

9. Roxburgh W. Flora Indica; or description of Indian plants. Vol. 2. Mision Press, Serampore; 1832. p. 519.

10. Turland NJ, Wiersema JH, Barrie FR, Greuter W, Hawksworth DL, Herendeen PS, Knapp S, Kusber WH, Li DZ, Marhold K, May TW, McNeill J, Monro AM, Prado J, Price MJ, Smith GF (eds.) 2018. International Code of Nomenclature for algae, fungi, and plants (Shenzhen Code) adopted by the Nineteenth International Botanical Congress Shenzhen, China, July 2017. Koeltz Botanical Books, Glashütten; 2018. (Regnum Veg. 159). https://doi.org/10.12705/Code.2018

11. Fyson PF. The Flora of the Nilgiri and Pulney Hill Tops. Vol.1. Superintendent Government Press, Madras; 1915. pp 134-135. https://doi.org/10.2307/2399958

12. Thompson MM. Survey of chromosome numbers in Rubus (Rosaceae: Rosoideae). Annals of the Missouri Botanical Garden, 1997; 84(1): 128-164.

13. Roxburgh W. Hortus Bengalensis, or a Catalogue of the Plants Growing in the Honourable East India Company's Botanical Garden at Calcutta. Mission Press, Serampore; 1814. p. 92. 